\title{
The Impact of Unfair Business Practices on Bank Customers: An Experimental Study
}

\author{
Adil Olmayan Işsletme Uygulamalarının Banka Müşterilerinin Niyetleri Üzerindeki Etkisi: \\ Deneysel Bir Çalışma
}

Volkan ÖZBEK', Ümit ALNIAÇIK², Fatih KOÇ³

\begin{abstract}
Ethics has become an attractive research topic in the business literature. However, experimental studies probing the relation between business ethics and perceived firm value are relatively scarce. Accordingly, in this study we examined how unfair business practices affect customers' perceptions about and intentions towards a company. For this aim, we conducted an experimental study on 406 university students. We used an excerpt to manipulate the information about a hypothetical bank's way of treatment to its customers (neutral vs. unfair). Than, we examined how different types of information do affect prospective customers' evaluations of firm reputation and their intentions to purchase services from the narrated bank. Data analysis revealed that, providing information about unethical business practices of a firm significantly decreased the perceived firm reputation and intentions to purchase services.

Keywords: Business ethics, perceived reputation, purchase intentions, marketing ethics, deceptive advertising, experimental methodology.
\end{abstract}

\section{LITERATURE REVIEW}

Direct concern for business ethics first appeared during the 1920s (Tsalikis and Fritzsche, 1989). However, concern for ethical issues in the business world has significantly increased over the last four decades. Corporate scandals (from Watergate to Enron and recently Goldman Sachs) have triggered both public and government scrutiny into business actions. Since the 1970s, the literature in marketing and business ethics has grown even more voluminous and diversified. An entire volume of research in corporate social performance and policy has been devoted to business ethics and values (Frederick and Weber, 1987). Today, there are dedicated journals (Journal of Business Ethics), special journal issues and text books about the issue.

Business ethics is a set of established rules, stan-

\section{ÖZET}

Etik konusu, işletme literatüründe önemli bir araştırma konusu olmuştur. Bununla birlikte, iş etiği ile algılanan firma değeri arasındaki ilişkileri inceleyen deneysel araştırmaların sayısı oldukça sınırlıdır. Bu araştırmada, adil olmayan is uygulamalarının, tüketicilerin bir firmaya ilişkin algılamalarını ve niyetlerini ne şekilde etkilediği araştırılmıştır. Bu amaçla, 406 üniversite öğrencisi üzerinde deneysel bir araştırma gerçekleştirilmiştir. Hipotetik bir bankanın müşterilerine davranış şeklini (nötr ve adaletsiz) maniple etmek için kısa bir hikaye kullanılmıştır. Daha sonra, farklı hikayeleri okuyarak farklı bilgiler alan deneklerin (potansiyel banka müşterileri) hikayede yer alan bankanın itibarı ile ilgili algılamalarının ve bu bankadan bankacilık hizmetleri alma niyetlerinin ne şekilde etkilendiği incelenmiştir. Yapılan analizler sonucunda bir bankanın sergilediği adil olmayan davranışlar ile ilgili bilgilendirilen cevaplayıcıların, o bankaya ilişkin itibar algılarının ve o bankadan hizmet alma niyetlerinin olumsuz yönde etkilendiği belirlenmiştir.

Anahtar Kelimeler: İ̧̧ etiği, algılanan itibar, satın alma niyeti, pazarlama etiği, yanıltıcı reklamlar, deneysel tasarım. dards, or principles for morally "right" behavioral conduct in specific situations (Stajkovic and Luthans, 1997). It requires that the organization or individual behaves in accordance with the carefully thoughtout rules of moral philosophy (Robin and Reidenbach, 1987). When a company is described as being ethical, then, this is usually referring to the degree to which it behaves in a moral or fair way (Cacioppe, Forster, Fox, 2008). Most of the models that have emerged are the products of scholars in psychology or related disciplines, including organizational behavior and marketing (Tseng, Duan, Tung, Kung, 2009). Among others, Trevino (1986) proposed a general theoretical model whereas Ferrell and Gresham (1985), Hunt and Vitell (1986), and Dubinsky and Loken (1989) offered models that focus on marketing ethics.

\footnotetext{
' Lecturer, Balıkesir University, Burhaniye School of Applied Sciences, Departmant of Business Administration,vozbek@balikesir.edu.tr

${ }^{2}$ Assist. Prof., Kocaeli University, Faculty of Communication, Department of Advertising, umit.alniacik@kocaeli.edu.tr

${ }^{3}$ Lecturer, Balıkesir University, Havran Vocational High School, fkoc@balikesir.edu.tr 
Marketing strategy does not exist in a vacuum free of ethical considerations anymore than other facets of business endeavor. In fact, it is likely that marketers face more ethical dilemmas than other businesspeople (Krohn and Milner, 1989, 773). Marketing ethics examines systematically marketing and marketing morality, related to $4 \mathrm{P}$-issues such as unsafe products, deceptive pricing, deceptive advertising or bribery, discrimination in distribution (Smith and Quelch, 1993, 13). Hunt and Vitell (1986) define marketing ethics as "an inquiry into the nature and grounds of moral judgments, standards, and rules of conduct relating to marketing decisions and marketing situations." From this perspective, unethical marketing behavior is any behavior within the marketing function that is illegal or morally unacceptable to the larger community (Jones, 1991). In most cases, there are certain legal arrangements to sort out legal and illegal marketing behavior. But sometimes it is difficult to distinguish what is morally acceptable or unacceptable, since the judgment of ethical behavior is in the eye of the beholder. Hence, marketing scholars and practitioners have long been interested in customers' perceptions of, and their reactions to different marketing practices. In particular, ethical considerations in advertising is a long standing issue. Advertising is the most visible and the most criticized component of marketing communications. Indeed, some questionable (i.e. ads to children, alcohol and tobacco ads, negative political ads) and deceptive advertising practices are the very reason for putting the advertising under fire. As a form of persuasive communication, advertising can easily be used to mislead the target audience. Consequently, ethical considerations in advertising is still an important area of research.

Extant research shows that responsible and ethical business practices pay off in the long run in better customer and employee relations (Alexander, 2002; Creyer and Ross, 1996; Folkes and Kamins, 1999; Smith and Cooper-Martin, 1997; Whalen et al., 1991). A growing number of polls, commercial reports and academic research indicate the positive effects of responsible firm behavior on business performance and stakeholder responses. According to Cone's "Cause Evaluation Survey", more than two-thirds (69\%) of Americans say they consider a company's business practices (such as impact on the environment, treatment of employees and financial transparency) when deciding what to buy (Cone, 2007). Murray and Vogel (1997) found that CSR actions significantly predict purchase intentions. Creyer and Ross (1996) determined that consumers' purchase intentions were related to whether the company's ethics record exceeded their expectation. Auger, Burke, Devinney, and Louviere, (2003) found that consumers expressed willingness to pay more for ethically made products.

Research also shows that questionable or unfair business practices may create serious penalties for the companies. The recent spate of corporate scandals in the USA, Europe, South-East Asia and Australia have demonstrated that unethical and immoral behavior by business organizations can have significant negative consequences for shareholders, employees, pension investment funds, customers and the many small businesses that had been trading with these companies (Cacioppe, et al., 2008). Unethical behavior may harm sales; worsen employee fraud, productivity and the risks from scandals. It may worsen employee retention, absenteeism and sabotage behavior (Josephson Institute, 2009). Employee attitude and behavior are heavily influenced by fairness of organizational actions towards them (Cropanzano, Byrne, Bobocel, \& Rupp, 2001). Unethical firm behavior may damage firm reputation and decrease consumer trust.

Credit cards usage constitutes an ever growing business field in the banking industry. Yet, their usage in the personal banking field resulted in a number of questionable business practices. Taking account of the fact that, credit cards have become a vital component of the Turkish economy since late $90 \mathrm{~s}$, we urge upon investigating the effects of objectionable practices on consumer behavior. In 2008, credit cards accounted for 25 percent of consumer spending, up from 22 percent in 2007, and now they are the most popular non-cash consumer payment instrument. Today, on average, there is nearly one credit card in circulation for every adult in Turkey. (Aydin, Guvendi, Pekmez, 2010). Credit cards are important and very profitable business for banks. They generate more than 10 percent of banking sector profits. This income has come almost entirely from the revolving business and annual membership fees (Aydin, Guvendi, Pekmez, 2010). Thus, banks implement aggressive campaigns to attract and retain as much credit card holders as possible. In particular, the amount of the expenditures made by university students and their potential of becoming bank customers in the future, stimulates many banks to develop campaigns for university students. The "Allowance Market 2010" survey conducted by a marketing communications agency "Youth Republic" and a research firm "Syno- 
vate" revealed that the total amaount of annual expenditures of 3 million university students in Turkey adds up to 22 Billion Turkish Liras, and approximately $77 \%$ of the students use credit cards. (Http:// www.hurriyet.com.tr/ekonomi/14453415.asp ) (Retrieved: 22.10.2011). Hence, many banks have initiated different credit card programs for university students (e.g., Akbank's "Axess-Neo exi26 Card", Is Bank's "Collegiate Card", Yapi Kredi Bank's "Play Club World Card", HSBC Bank's "Campus Card", Garanti Bank's, "Unibank Card", Finans Bank's "CardFinans University". Further, many Turkish banks provide students higher education credits and college loans. (http://www.bankalar. org/krediler/egitim-kredisi) (Retrieved: 22. 10.2011). This hustle market frequently results in consumer complaints regarding unfair business practices. Thus it is an abundant area for ethics research. A review of the few studies made in the Turkish context revealed that unethical behavior of firms in Turkish banking sector significantly affects consumer attitudes and behavior (Kurtuldu, 2009). In another study conducted on college students, it was found that the ads did not reflect the reality and deceived the consumers (Dundar and Goksel, 2006: 139). In another study conducted among Turkish and Kazakh executives, Turkish executives found to have higher ethical standards than their Kazakh counterparts, by using the ATBEQ scale (Nurmakhamatuly, 2010: 91).

The literature review exerts that the concept of business ethics and most of the empirical work on the topic originate from developed countries. Research from underdeveloped or developing countries is relatively scarce. Further, a vast majority of the empirical research used the survey (questionnaire) method to investigate the issue of business ethics and its impact on customer attitudes and behavior. Experimental studies pursuing the effects of ethics on customer responses are also rare. This study aims to make up this shortcoming to some degree, by providing experimental evidence from a developing country (Turkey). Particularly, in this study we examined how unfair business practices of a bank affects customers' perceptions about the Bank's reputation and their intentions to purchase services from the Bank. In accordance with the findings of the past research, we proposed the following hypotheses:

Hypothesis 1: Providing information about unfair business practices of a bank will diminish the perceived reputation of that bank.

Hypothesis 2: Providing information about unfair business practices of a bank will decrease customers' intentions to purchase services from that bank.
In order to test these hypotheses, we conducted an experimental study. In the next section, experimental design and research procedure is explained.

\section{METHODOLOGY}

\subsection{Experimental Design and Procedure}

A single factor between subjects experimental design consisting of two treatment levels was used in this study. The experimental factor was a hypothetical bank's way of treatment to its customers, which was manipulated by a vignette (a short story of 200 words). The story was selected amongst a number of real life experiences narrated by a group of university students, in a pilot study. The short story described a "XYZ Bank" that was recently announced a special offer for consumer credits. Research instrument was a questionnaire, which had the vignette on one side, and the relevant questions on the other side. Two versions of the vignette were produced for generating the experimental conditions. In the first version (neutral version), XYZ Bank's treatment to its customers was described in a neutral perspective (The Bank announced a special offer for consumer credits. In the ads, it clearly declared that the special offer was devoted to the customers who own the Bank's credit card). In the second version (unfair treatment version), the Bank's treatment to its customers was storied in a negative manner (The Bank announced a special offer for consumer credits. However, it withheld the information that the special offer was devoted to the customers who own the Bank's credit card. "Mr. A" went to the Bank's office, and learned about this condition in the last minute. Since he desperately needed the loan, he was constrained to obtain the credit card). Similar procedures were successfully used in previous studies (Goldberg and Hartwick 1990; Dollinger, Golden and Saxton, 1997). Although it is an artificial situation, the vignette methodology provides the researcher with the ability to manipulate the different factors and see how people would deal with it if they were in that situation (Greenhaus and Gary Powell, 2004). By employing systematic variation in vignette content, the researcher is able to measure the determinants of respondent opinion more accurately than could be accomplished by the use of direct questioning (Alexander, Becker, 1978).

A total of 406 undergraduate students studying at various departments of a large Turkish university participated in this study as part of classroom activities. The mean age of subjects was 21 years $(s d .=2.53)$ and $54 \%$ were female. Experiments were done in groups of 40 to 70 students. In each group, 
subjects were randomly assigned to either condition. 203 students were assigned to the "neutral information" condition, and 203 students were assigned to the "negative information" condition. Experiments were conducted by lecturers, who gave short explanations to the participants before the procedure. The explanation did not convey the real purpose of the experiment. Instead, participants were told that, the purpose was to understand their attitudes towards banking services advertisements. Subjects were asked to read through the story at their own pace. After reading the story, they completed post-test measures and manipulation checks. Questionnaires were then collected and subjects were thanked.

\subsection{Measures}

The study had two dependent variables. The first dependent variable was subjects' perceptions about the firm reputation, was assessed with 4 Likert type scales derived from Newell and Goldsmith (2001) and Walsh and Beatty (2007). Subjects were instructed by the following sentence: "Assume that you need some cash and you are in search for a personal installment loan. To what extent you agree or disagree with the following statements about XYZ Bank?" The second dependent variable, subjects' intentions to purchase services from XYZ Bank, was assessed with 4 Likert type scales, derived from the Behavioral Intentions Battery (Zeithaml et al., 1996). Subjects were asked "To what extent you agree or disagree with the following statements about purchasing banking services from a bank like XYZ?" Level of agreement or disagreement with items were reported on five point scales, ranging from $1=$ Completely Disagree to $5=$ Completely Agree.

In order to check the effectiveness of the manipulations, perceived ethicality (of the alternative patterns of firm behavior) was measured by 8 semantic differential scales derived from Reidenbach and Robin (1990). Scale items include: righteous-not righteous, fair-unfair, just-unjust, honest-dishonest, culturally acceptable-unacceptable, traditionally acceptable-unacceptable, morally right-wrong, acceptable-unacceptable, All of the scales were 7 point bi-polar scales and answers ranged from $(-3)$ to $(+3)$. They were coded in such a way that higher scale values indicated a higher level of fairness. Subjects were instructed to assess the fairness of XYZ Bank's narrated behavior. They were warned to make their assessments merely based on the short story they read.

\section{DATA ANALYSES}

\subsection{Manipulation Checks}

Dimensionality of the perceived fairness scale was assessed by exploratory factor analyses. Eight items loaded on a single factor. This single factor explained $75.3 \%$, of the total variance (eigenvalue $=6,03$ ). Thus, a composite measure was created by averaging the responses on the eight items. The composite variable was named as "perceived ethicality". The Cronbach alpha reliability of the composite measures was .95 . Independent samples $t$ test was performed to verify if the perceived level of ethicality varied in the alternative experimental conditions. Results of the $t$ test indicate a significant difference between the different conditions ( $t(404)$ $=10.41 ; p<0,001)$. Control treatment (neutral information) attained a mean score which was very close to the middle point $(M=.028$; $s d .=1.78)$ as expected. The "negative information" version attained a lower mean score $(M=-1.38$; $s d .=1.4)$. These results verified that the perceived ethicality of XYZ Bank's behavior had a significantly lower score in the "negative information" condition, compared to the neutral information condition (See Table 1). The hypothetical XYZ Bank's perceived fairness is worse in the "negative information" than the "neutral" version. Thus, the experimental manipulation was found to be successful.

\subsection{Evaluation of Dependent Measures}

Factor and reliability analyses were carried out to examine the dimensionality and reliability of the dependent measures. Perceived reputation of the focal company was measured by using a four-item scale. Scale dimensionality was assessed by exploratory factor analyses. This single factor explained $79.8 \%$ of the total variance (eigenvalue $=3,19$ ). Thus, a composite measure was created by averaging the responses on the seven items. The composite variable was named as "Perceived Firm Reputation". The Cronbach alpha reliability of the composite measures was .92 .

Intentions to purchase services from the focal bank were measured by using another four-item scale. Scale dimensionality was assessed by exploratory factor analyses. Four items measuring purchase intentions were loaded on a single factor. This single factor explained $77.1 \%$, of the total variance (eigenvalue $=3,09$ ). Thus, a composite measure was created by averaging the responses on the four items. The composite variable was named as "Purchase Intentions". The Cronbach alpha reliability of the composite measures was .90. Table 1 shows means and standard deviations of the scale items for different experimental conditions. 
Table 1: Scale Items' Means and Standard Deviations According to Different Experimental Conditions

\begin{tabular}{|c|c|c|c|c|c|}
\hline \multirow[t]{2}{*}{ SCALE } & \multirow[t]{2}{*}{ ITEMS } & \multicolumn{2}{|c|}{ Neutral } & \multicolumn{2}{|c|}{$\begin{array}{c}\text { Unfair } \\
\text { Treatment }\end{array}$} \\
\hline & & Mean & Sd. & Mean & Sd. \\
\hline \multirow{5}{*}{$\begin{array}{l}\text { Perceived Firm } \\
\text { Reputation* }\end{array}$} & This bank has a good reputation among customers & 3,12 & 1,28 & 2,11 & 1,19 \\
\hline & This bank provides high quality products and services & 3,12 & 1,13 & 2,36 & 1,10 \\
\hline & This bank keeps its promises & 3,02 & 1,19 & 2,08 & 1,20 \\
\hline & Overall image of this bank is positive & 3,26 & 1,21 & 2,33 & 1,22 \\
\hline & Overall & 3,13 & 1,06 & 2,22 & 1,02 \\
\hline \multirow{5}{*}{$\begin{array}{l}\text { Intentions to } \\
\text { Purchase } \\
\text { Banking } \\
\text { Services* }\end{array}$} & I would love to be a customer of this bank & 3,04 & 1,18 & 2,13 & 1,15 \\
\hline & I can safely entrust my money and other savings to this bank & 3,05 & 1,13 & 2,36 & 1,19 \\
\hline & I would recommend this bank to my friends and relatives & 3,06 & 1,19 & 2,18 & 1,14 \\
\hline & If I was a customer of this bank, I would never think to switch to another & 2,84 & 1,20 & 2,26 & 1,23 \\
\hline & Overall & 3,00 & 1,00 & 2,23 & 1,03 \\
\hline \multirow{9}{*}{$\begin{array}{l}\text { Perceived } \\
\text { Fairness** }\end{array}$} & Unfair-Fair & $-0,13$ & 2,25 & $-1,63$ & 1,63 \\
\hline & Unjust-Just & 0,50 & 2,24 & $-1,81$ & 1,65 \\
\hline & Not Righteous-Righteous & 0,34 & 2,12 & $-1,42$ & 1,73 \\
\hline & Culturally Unacceptable-Acceptable & 0,20 & 1,85 & $-1,03$ & 1,62 \\
\hline & Traditionally Unacceptable-Acceptable & 0,13 & 1,75 & $-1,10$ & 1,50 \\
\hline & Not Morally Right-Morally Right & 0,10 & 2,00 & $-1,55$ & 1,63 \\
\hline & Violates -Not Violates Marketplace Promise & 0,51 & 2,30 & $-1,38$ & 2,06 \\
\hline & Unacceptable-Acceptable & 0,61 & 2,09 & $-1,14$ & 1,96 \\
\hline & Overall & 0,28 & 1,78 & $-1,38$ & 1,40 \\
\hline
\end{tabular}

* Responses ranged from $1=$ Completely Disagree to $5=$ Completely Agree.

** Responses ranged from $(-3)$ to $(+3)$.

\subsection{Results}

In order to test the first hypothesis, the first dependent variable, perceived firm reputation of the focal company, was submitted to independent samples $t$ test. $T$ test results indicated a significant difference between the different experimental conditions ( $\mathrm{t}(405)$ $=8.762 ; p<0,001$ ). Control treatment (neutral information) attained a mean score which was close to the mid-point $(M=3.13$; sd.=1.06). The "negative information" version attained a lower mean score of perceived reputation $(M=2.22 ; \mathrm{sd} .=1.02)$. These results verified that the perceived reputation of XYZ Bank was significantly decreased in the "negative information" condition compared to the neutral information condition. Thus, Hypothesis 1 was supported.
In order to test the second hypothesis, other dependent variable, intentions to purchase banking services from XYZ Bank, was also submitted to independent samples $t$ test. T test results indicated a significant difference between the different experimental conditions $(t(405)=7.611 ; p<0,001)$. Control treatment (neutral information) attained a mean score which was on the midpoint $(M=3.00$; $s d .=1.005)$. The "negative information" version attained a lower mean score $(M=2.23 ; \mathrm{sd}$. $=1.026)$. These results were in accordance with the second hypothesis which anticipated that, providing information about unfair business practices of a bank will decrease customers' intentions to purchase services from that bank. Mean scores of the dependent variables for different experimental conditions are presented in Figure 1.

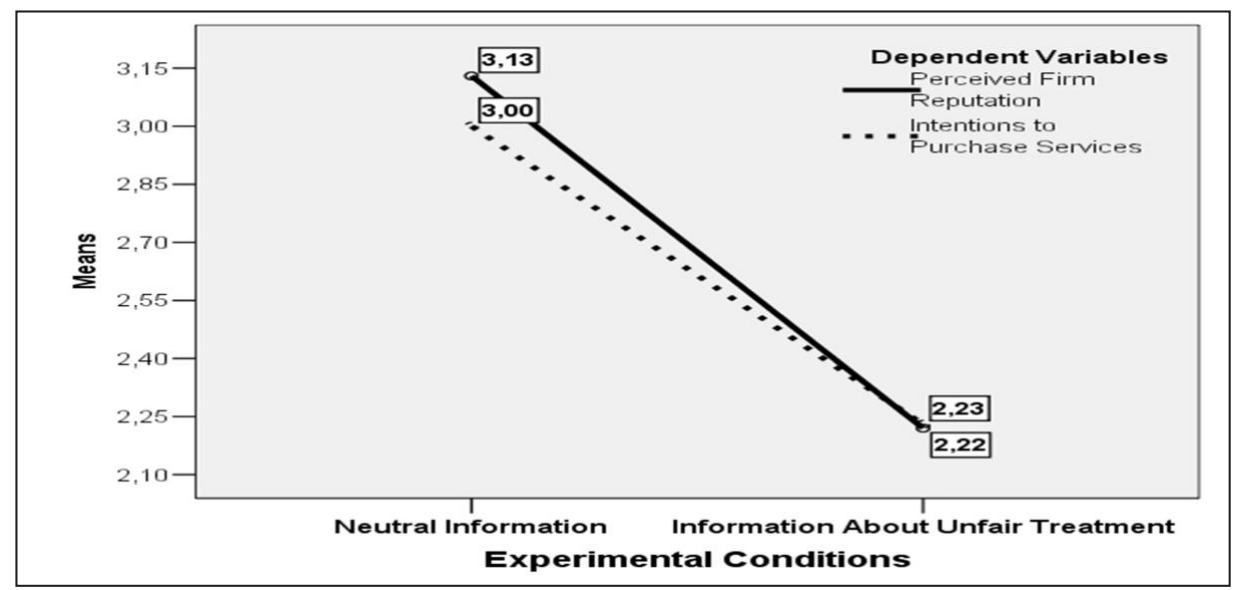

Figure 1: Mean Scores of the Dependent Variables for Different Experimental Conditions 


\section{DISCUSSION AND IMPLICATIONS}

In this study, we examined how unfair business practices affect customers' perceptions about a bank's reputation and their intentions to purchase services from the bank. We set an experimental design and manipulated the information about a hypothetical bank's way of treatment to its customers. Dependent variables of the study were perceived reputation of the focal bank, and respondents' intentions to purchase services from that bank.

Data analysis revealed that, unfair banking practices (compelling customers to acquire a credit card) damaged the perceived reputation of the bank, and significantly decreased respondents' intentions to purchase services from that bank. These results are in accordance with the extant literature about business ethics and its impact on consumer behavior.

Further, the results provide important managerial implications for the banking industry, concerning the issue of credit cards. As mentioned earlier, the credit card market is growing day by day and banks are trying to get higher shares from this growth. Hence, they are using all of their financial and marketing power to attract new customers (Aysan and Yildiz, 2007). Yet, sometimes they go beyond the indistinct boundaries of business ethics. This study shows that, banking executives must be very careful when planning and implementing their efforts on credit card marketing. Suspicious practices may damage their reputation and create unfavorable attitudes towards their firm. This is particularly important when ethically questionable practices take place. It must be clearly understood how customers interpret a questionable application, before putting it into practice.

\section{LIMITATIONS AND FUTURE RESEARCH DIRECTIONS}

The study has some limitations. First of all, it was conducted with the use of student subjects in a contrived setting. Using artificial narratives about a hypothetical bank in a questionnaire may have created a higher level of task involvement than a natural setting would do. But this does not compromise the internal validity of the experiment, since we believe that this factor might have affected the different treatment groups in a similar way. University students are a suitable target group for this study since they are an important customer group for the banking services. However, there is a need to replicate this research with the use of other population groups. Future studies would gain external validity by using probability samples of wider populations including non-student participants. We also used a fictitious company to avoid any biased effects due to previously acquired knowledge. In future research, more realistic experimental settings may be designed by using real reports about factual firms. Further, due to the sensitive nature of business ethics, social desirability may present an incrementally greater risk to the validity of findings in ethics research, relative to other, more conventional studies in organizational behavior (Randall and Fernandes, 1991). As another limitation, it has to be noted that authors did not utilize any procedure to control the potential social desirability bias, except using a fictitious company name in the vignettes. Future studies should consider developing procedures to control any social desirability bias. 


\section{REFERENCES}

Alexander, E.C. (2002) "Consumer Reactions to Unethical Service Recovery" Journal of Business Ethics, 36(3):223- 237.

Alexander C. S. and Becker H. J. (1978) "The Use of Vignettes in Survey Research" Public Opinion Quarterly, 42:93- 104

Auger, P., Burke, P., Devinney, T.M. and Louviere, J.J. (2003) "What Will Consumers Pay for Social Product Features?” Journal of Business Ethics, 42(3):281- 304.

Aydin, E., Guvendi, M. and Pekmez, E. (2009) "Credit Cards in Turkey: Sustaining a Successful Market" http://www.mckinsey.com/clientservice/Financial_Services/Capabilities/ /media/Reports/Financial_Services/Credit_Cards_in_Turkey.ashx, (14.03.2010),

Aysan, A.F. and Yildiz, L. (2007) "The Regulation of the Credit Card Market in Turkey" International Research Journal of Finance and Economics, 11:141- 154.

Cacioppe, Ron, Forster, N. and Fox, M. (2008) "A Survey of Managers' Perceptions of Corporate Ethics and Social Responsibility and Actions That May Affect Companies' Success" Journal of Business Ethics, 82(3): 681700 .

CONE (2007) "Cause Evolution Survey" http://www. coneinc.com/stuff/contentmgr/files/0/A8880735bb2e2e894a949830055ad559/Files/2007_Cause_Evolution_Survey.Pdf, (22.09.20009),

Creyer, E.H. and Ross, W.T. (1996) "The Impact of Corporate Behavior on Perceived Product Value" Marketing Letters, 7(2):173- 185.

Cropanzano, R., Byrne, Z.S., Bobocel, D.R. and Rupp, D.R. (2001) "Moral Virtues, Fairness Heuristics, Social Entities, and Other Denizens of Organizational Justice" Journal of Vocational Behavior, 58(2):164- 209.

Dollinger, M.J., Golden P.A. and Saxton T., (1997) "The Effect Of Reputation On The Decision To Joint Venture" Strategic Management Journal, 18(2):127- 140.

Dubinsky, A.J. and Loken, B. (1989), "Analyzing Ethical Decision Making in Marketing" Journal of Business Research, 19(2):83- 107.

Dundar, S. and Göksel T., (2006) "Reklamların Pazarlama Etiği ve Sosyal Sorumluluk Bilincine Göre Değerlendirilmesi: Ampirik Bir Çalışma” Afyon Kocatepe Üniversitesi İ̈BF Dergisi, 8(1):123- 141.

Ferrell, O.C. and Gresham, L.G. (1985) "A Contingency Framework for Understanding Ethical Decision Making in Marketing" Journal of Marketing, 49(3):87-96.
Folkes. V. S. and Kamins, M. A. (1999) "Effects of Information About Firms' Ethical and Unethical Actions on Consumers' Attitudes" Journal of Consumer Psychology, 8(3):243-259.

Frederick, W.C. and Weber, J. (1987) "The Values of Corporate Managers and Their Critics: An Empirical Description and Normative Implications", Frederick W. (eds.) Research in Corporate Social Performance and Policy, Greenwich, JAI Press.

Goldberg, M.E. and Hartwick J., "The Effects of Advertiser Reputation and Extremity of Advertising Claim on Advertising Effectiveness" Journal of Consumer Research, 17(4):172- 179.

Greenhaus J. and Powell G. (2004) "The Vignette Methodology: Study Uses Stories to Measure Conflict" Methods and Measures in Work-Family Research, 6(2):4-5.

Hunt, S.D. and S.A. Vitell. (1986) "General Theory of Marketing Ethics” Journal of Macromarketing, 6(1):5-16.

Jones. T. M. (1991) "Ethical Decision Making by Individuals in Organizations: An Issue-Contingent Model" Academy of Management Review, 16(2):366- 395.

Josephson Institute (2009) "The Hidden Costs of Unethical Behavior" http://josephsoninstitute.org/pdf/ workplace-flier_0604.pdf, (04.03.2010).

Krohn, F.B. and Milner, L.M. (1989) "The AIDS Crisis: Unethical Marketing Leads to Negligent Homicide" Journal of Business Ethics, 8(10):773-780.

Kurtuldu, H. S. (2009) "Bankacılıkta Pazarlama Etiği ve Etik Değerlerin Kuruma Yönelik Olumlu Tutum Oluşumuna Etkileri” Uluslararası İktisadi ve İdari İncelemeler Dergisi, 1(2): 83- 96.

Murray, K.B. and Vogel, C.M. (1997) "Using a Hierarchy-of-Effects Approach to Gauge the Effectiveness of Corporate Social Responsibility to Generate Goodwill Toward the Firm: Financial Versus Nonfinancial Impacts" Journal of Business Research, 38(2):141-159.

Newell, S.J. and Goldsmith, R.E. (2001) "The Development of A Scale to Measure Perceived Corporate Credibility" Journal of Business Research, 52(39):235-247.

Nurmakhamatuly, A. (2010) "Attitudes and Behaviors Towards Business Ethics of Kazakh and Turkish Managers" Turkish Journal of Business Ethics, 3(5):69-96.

Randall, D. M. and Fernandes M. F. (1991) "The Social Desirability Response Bias in Ethics Research" Journal of Business Ethics, 10(11):805-817. 
Reidenbach, R.E., and Robin, D.P. (1990) "Toward the Development of a Multidimensional Scale for Improving Evaluations in Business Ethics" Journal of Business Ethics, 9(8):639-653.

Robin, D.P. and Reidenbach, R.E. (1987) "Social Responsibility, Ethics, and Marketing Strategy: Closing the Gap Between Concept and Application" Journal of Marketing, 51(1): 44-58.

Smith, N.C. and Cooper-Martin, E. (1997) "Ethics and Target Marketing: The Role of Product Harm and Consumer Vulnerability" Journal of Marketing, 61(3):120.

Smith, N. C. and Quelch, J. A. (1993) "Ethics in Marketing" Irwin, Burr Ridge, IL.

Stajkovic, A.D. and Luthans, F. (1997) "Business Ethics across Cultures: A Social Cognitive Model” Journal of World Business, 32(l):17-34.

Trevino, L. K. (1986) "Ethical Decision Making in Organizations: A Person-situation Interactionist Model" Academy of Management Review, 11(3):601-617.
Tsalikis, J. and Fritzsch, D. (1989) "Business Ethics: A Literature Review with a Focus on Marketing Ethics" Journal of Business Ethics, 8(2):695-743.

Tseng, H., Duan, C., Tung, H. and Kung, H. (2009) "Modern Business Ethics Research: Concepts, Theories, and Relationships" Journal of Business Ethics, 91(4):587597.

Walsh, G. and S. E. Beatty (2007) "Customer-Based Corporate Reputation of A Service Firm: Scale Development and Validation" Journal of the Academy of Marketing Science, 35(1):127-143.

Whalen, J., Pitts, R.E. and Wong, J.K. (1991) "Exploring the Structure of Ethical Attributions as a Component of the Consumer Decision Model: The Vicarious Versus Personal Perspective" Journal of Business Ethics, 10(4):285-293.

Zeithaml V.A., Berry L.L. and Parasuraman A. (1996) "The Behavioral Consequences of Service Quality” Journal of Marketing , 60(2):31- 46. 